\title{
HTLV-I/II Infection and Connective Tissue Disorders
}

\section{Infecção por HTLV-I/II e Doenças do Tecido Conjuntivo}

\author{
Patrícia Caspary $^{(1)}$, Márcio Menna-Barreto ${ }^{(2)}$, Henrique Luiz Staub $^{(3)}$
}

\section{TO THE EDITOR}

The human T-lymphotropic virus (HTLV) is a potentially imumne stimulatory agent through interacting with helper T cells. Autoimmune phenomena are not rare in patients infected by this retrovirus ${ }^{(1)}$.

We read with interest the manuscript by Carvalho et al that was recently published in this Journal. The study evaluated the frequency of connective tissue disorders (CTD) in patients infected by HTLV-1. The authors studied 137 patients (27 with myelopathy). As a whole, Sjögren syndrome (SS) (17,5\%) and rheumatoid arthritis $(R A)(13,1 \%)$ were the most frequent $C T D$ in their survey. Of note, both SS and RA were more significantly found in patients with myelopathy than in asymptomatic carriers $^{(2)}$.

We recently looked at the clinical and laboratory findings of 9 patients with HTLV-I/II-associated myelopathy. Patients were selected on the basis of a preexisting concomitant $C T D^{(3)}$. Eight patients (89\%) were female, and the mean age was 49 years. Of interest, 2 patients (22\%) were HTLVII positive. SLE was the most prevalent CTD in our survey ( 5 patients - 55\%). Primary SS was seen in 4 patients (44\%), one of them was also diagnosed as presenting associated antiphospholipid antibody syndrome. In general terms,

\section{REFERENCES}

1. Hollsberg P, Hafler DA: Pathogenesis of disease induced by human lymphotropic virus type I infection. NEJM 328: 117382,1993 .

2. Carvalho MMN, Giozza SP, Santos ALMA, Carvalho EM, Araújo MI: Freqüência de manifestações reumáticas em indivíduos infectados pelo HTLV-I. Rev Bras Reumatol 46: 315-22, 2006. primary or secondary SS were documented in 7 patients (78\%). There was no patient diagnosed with $R A$.

As compared to the above mentioned report, our experience presented different results coupled to a decreased prevalence of myelopathy. Some aspects are worthy of comment, nevertheless. HTVL-II infection was present in 2 of our 9 patients (22\%). There is no mention to HTLV-II infection in the Carvalho et al study ${ }^{(3)}$. Also, in contrast to their report ${ }^{(3)}$, we had no patient diagnosed with $R A$. On the other hand, SLE was frequent in our series, whereas it was extremely rare in the other study ${ }^{(3)}$. Both studies ${ }^{(2,3)}$ agreed as to the highly significant prevalence of SS associated to HTLV infection.

In another strategy, we investigated the presence of antibodies against HTLV-I/II viruses in 69 cases of patients presenting with $R A$ and 33 SLE patients. The frequency of antibodies against HTVL-I was significantly greater in $R A$ patients (7\%), as compared to healthy controls $(1,28 \%)(P=0,004)$. This finding was not confirmed in our SLE cohort ${ }^{(4)}$.

The apparent discrepancies between both studies may me at least partially be related to differences in patient selection and study design. The relationship of HTLV-I/II infection to autoimmune disorders remains enigmatic, pointing to the need for additional studies on this subject.

3. Caspary P, Menna-Barreto M, Staub HL: Doenças do tecido conjuntivo em pacientes com mielopatia crônica associada ao HTLV-I/II (Submitted).

4. Lonzetti LS, Menna-Barreto M, Schoeler M, Antonini E, Staub HL, Keiserman M: Anticorpos anti-human T-lymphotropic virus tipos I e II (HTLV-I/II) em pacientes com artrite reumatóide. Rev Bras Reumatol 39: 211-16, 1999.

\footnotetext{
1. Médica residente de Medicina Interna, Faculdade de Medicina da Pontifícia Universidade Católica do Rio Grande do Sul (PUCRS).

2. Doutor em Neurologia, médico do Serviço de Neurologia da PUCRS.

3. Doutor em Reumatologia, professor adjunto de Reumatologia da Faculdade de Medicina da PUCRS.

Address for correspondence: Henrique Luiz Staub, Hospital São Lucas, Pontifícia Universidade Católica do Rio Grande do Sul (PUCRS), Avenida Ipiranga, n $6690 / 220$ Porto Alegre, RS, Brasil, CEP 90610-000. e-mail: reumato@pucrs.br
} 